\title{
Breastfeeding in Turkey: A Systematic Review
}

\author{
Tulay Yilmaz $^{1}$, Husniye Dinc Kaya ${ }^{1}$, Sevil Gunaydin ${ }^{1}$, Nukhet Kacar $^{2}$ (D) \\ ${ }^{1}$ Istanbul University-Cerrahpasa, Faculty of Health Science, Department of Midwifery, Istanbul, Turkey. \\ ${ }^{2}$ Ankara City Hospital-Maternity Hospital, Ankara, Turkey. \\ Correspondence Author: Tulay Yilmaz \\ E-mail: tyilmaz@istanbul.edu.tr, tulaymert@hotmail.com \\ Received: $14.12 .2020 \quad$ Accepted: 28.06.2021
}

\begin{abstract}
Objective: This study was carried out to systematically review the studies conducted on breastfeeding in Turkey and to provide information on the breastfeeding status.

Methods: This study is a systematic review and conducted by examining 47 studies carried out in Turkey between January 2008-December 2018 and published in national and international journals. The methodological quality of the studies was examined according to the evaluation criteria of the Joanna Briggs Institute Critical Appraisal Checklist for Studies Reporting Prevalence Data. The Preferred Reporting Items for Systematic Reviews and Meta-Analyses checklist was used while reporting the review.

Results: According to the obtained study results, it was determined that the time of breastfeeding initiation and the mean duration of breastfeeding were in quite a wide range. Among breastfeeding-related factors, maternal age, education, employment status, the number of living children, the type of birth, preterm birth, receiving professional support on breastfeeding, early postnatal breastfeeding, and giving complementary feeding or formula were frequently listed. The most common reason for starting complementary feeding or was determined to be the idea that breast milk was insufficient.

Conclusion: No common language and unity of definition were observed in the studies reviewed. The studies were conducted in different samples. It is thought that the systematization of studies on breastfeeding will be scientifically useful for determining the current situation, determining the scope of future studies, and making the necessary arrangements.
\end{abstract}

Keywords: Breastfeeding, Breast milk, Turkey, Systematic review

\section{INTRODUCTION}

The World Health Organization (WHO) states that breastfeeding is the most effective way to provide infants with nutrients they need for growth and development (1). The World Health Organization and the United Nations International Children's Emergency Fund (UNICEF) recommend that mothers should start to breastfeed their infants within the first hour after birth $(2,3)$.

Furthermore, it is recommended that mothers should maintain exclusive breastfeeding in the first 6 months without giving any food or drinks including water. It is also recommended to maintain breastfeeding for their infants at night and during day time at frequencies their infants want, not to use by not using a feeding bottle or a pacifier. After the 6th month of infants, it is recommended to continue breastfeeding until at least 2 years of age or older, provided that breastfeeding is accompanied by appropriate complementary feeding $(2,3)$.

Breastfeeding has many benefits for the infant. While providing the emotional and cognitive development of infants, it also protects them against infections and strengthens the immune system. Moreover, it protects against otitis media, gastroenteritis, necrotizing enterocolitis, sudden infant death syndrome, atopic skin diseases, respiratory tract and urinary tract infections, bacterial meningitis, allergic diseases, acute and chronic diseases such as obesity, diabetes, celiac disease, and childhood leukemia, and accelerates the healing process. Research also shows that very early skin-to-skin contact and suckling may have physical and emotional benefits (1-5).

The Turkey Demographic and Health Survey (TDHS, 2018) defines not giving children anything other than breast milk, in other words, feeding children only with breast milk as 
"Exclusive breastfeeding." According to the survey, only $41 \%$ of children younger than 6 months were exclusively breastfed. Exclusive breastfeeding rate decreases rapidly with age. While the rate of exclusive breastfeeding in 0-1 months old infants is $59 \%$, this rate decreases in 2-3 months and $4-5$ months old infants to $45 \%$ and $14 \%$ respectively $(2,6)$.

There are many sociodemographic, obstetric, and breastfeeding-related factors that affect mothers' exclusive breastfeeding. Sociodemographic factors include maternal age, educational status, employment status, economic status, family type, environmental factors, hospital conditions where birth will take place, and cultural factors (7-9). Obstetric factors include age of gestation, parity and number of living children, and type of birth (10-13). Breastfeeding-related factors include counseling on breastfeeding received by mother during pregnancy, self-confidence in breastfeeding, mother's attitude toward breastfeeding and healthcare professionals' attitude toward breastfeeding, thinking that breast milk is insufficient, unwillingness to breastfeed, giving formula in hospital, and use of a pacifier (7-10,14-16).

This systematic review was carried out to systematically review studies conducted on breastfeeding in Turkey and to provide information on breastfeeding status, and the time of breastfeeding initiation, breastfeeding duration, factors affecting breastfeeding, and reasons for starting complementary feeding were determined.

\section{METHODS}

The Preferred Reporting Items for Systematic Reviews and Meta-Analyses (PRISMA) checklist was used in preparation of systematic review protocol and writing of article $(17,18)$. This checklist has a Turkish text (19).

\subsection{Search}

Literature review was conducted by performing retrospective screening of publications on subject through search engines by using internet access network of Istanbul UniversityCerrahpaşa. Literature review was performed using various combinations of keywords of breastfeeding, breast milk, and Turkey in Turkish and English. It was performed using search engines of Electronic databases, Google Scholar, Medline, CINAHL, Embase, Cochrane Library, ULAKBIM, and Türk Tıp Dizi. In order to reach current research data, studies published in a period of 10 years (January 2008-December 2018) were included in study.

\subsection{Study selection}

Research articles to be included in study were determined by a consensus of two researchers. Discrepancies that occurred between researchers in meantime, whether an article should be included in the study or not, were resolved by reaching a consensus as a result of review by a third researcher.

\subsection{Eligibility criteria}

Studies conducted in Turkey and published in national/ international refereed journals between January 2008-December 2018, with sample containing healthy mothers and infants, with original and quantitative characteristics, and full text of which could be reached were included in research. Repeated publications were eliminated during selection. Unpublished theses on subject, books/ book chapters, reviews, qualitative studies, experimental studies, oral or poster papers presented at congresses, and studies data of which were not collected in Turkey and not having sample group of healthy infants and children were not included in study (Figure 1).

\subsection{Protocol and registration}

Titles and abstracts of all studies determined by electronic search were examined by two researchers independently of each other in terms of eligibility criteria. One researcher evaluated methodological quality of articles that met eligibility criteria according to the Joanna Briggs Institute (JBI) Critical Appraisal Checklist for Studies Reporting Prevalence Data (20). Evaluations made were checked by another researcher.

\subsection{Data collection process}

A pre-designed form was used independently by two researchers for data collection. With this form, years of publication of studies, their types, characteristics of sample group, place of study data collection, definition of questionnaire and scales used, time of breastfeeding initiation, duration of breastfeeding, breastfeeding-related factors, and reasons for starting complementary feeding were descriptively summarized by two researchers in an Excel table. This summarized information was checked by another researcher. In contradictory cases, three researchers reached a consensus.

\subsection{Research Questions:}

1. What is the time of breastfeeding initiation?

2. What is the duration exclusively breastfeeding?

3. What is the total duration of breastfeeding?

4. What are the factors related to breastfeeding?

5. What are the reasons for starting complementary feeding?

\subsection{Data items}

After literature review, 1755 studies were reached on subject in electronic environment at first stage. After removal of repeated publications, 858 studies were evaluated. Study titles and abstracts were examined, and 718 studies were excluded from study. Full text of 140 studies was reached and 
analyzed. Accordingly, 93 studies that did not meet inclusion criteria were excluded. Systematic review data were collected by examining 47 studies. Details of article selection process are presented in Figure 1.

\subsection{Data Analysis}

Due to the fact that data obtained from examined studies were not homogenous, a meta-analysis could not be performed. Quantitative data on the time of breastfeeding initiation and duration of breastfeeding in studies were given as minimum and maximum values considering all studies. Methodological quality of studies was evaluated by the JBI Critical Appraisal Checklist for Studies Reporting Prevalence Data. In this evaluation system, quality of studies is determined by scoring between 1 and 9 . Mean score of 47 studies examined was determined to be $6.58 \pm 1.0$.

\section{RESULTS}

Results of review will be evaluated under two separate headings:

\subsection{Results of study characteristics are as follows}

1. Publication years and types of studies

2. Characteristics of sample group

3. Place of study data collection

4. Questionnaire and scales used in studies

\subsection{Results of breastfeeding are as follows}

1. Results on the time of breastfeeding initiation

2. Results on the duration of exclusively breastfeeding and total breastfeeding

3. Results on breastfeeding-related factors

4. Results on the reasons for starting complementary feeding

\subsection{Results of study characteristics}

\subsubsection{Publication years and types of studies}

Upon examining number of studies by years, highest number of publications on subject (eight publications) was in 2018, followed by 2012 with seven publications. In 2013 and 2017, there were six publications in each of years. There were five publications in 2008, four publications in 2010 and 2015, three publications in 2009, and two publications in 2014. Besides, in 2011 and 2016, there was only one publication in each of years. Of the 47 studies examined, 41 studies were determined to be descriptive-cross-sectional $(4,21-60)$ three studies were retrospective $(7,61,62)$, three studies were prospective (63-65) follow-up studies.

\subsubsection{Characteristics of Sample Group}

Upon examining sample number of reviewed studies, it was observed that studies were conducted with 51 people at least (58) and with 3038 people at most (26). Age range of children of mothers included in study varied and was determined to cover groups of neonates $(7,34,39,43,45,50,51,58,63), 0-3$ months $(30,42)$, 0-6 months $(22,27,41,47,53,56,64,65), 0-12$ months $(4,23,24,28,29,54,61,62), 0-18$ months $(32,44), 0-24$ months $(25,33,35-37,46,48,49,52,55,57,59,60)$, and $0-36$ months $(26,31)$. In other studies, children in $0-5$ age range $(21,38,40)$ were studied in different time periods.

\subsubsection{Place of Study Data Collection}

Places where reviewed studies were conducted and data were collected vary. Of studies, 16 were performed in primary health care centers $(4,23,24,26,29,32,37,38,41,44,47,49,52,5$ $4,55,57), 22$ were performed in polyclinics for healthy children and other polyclinics of hospitals $(7,21,22,27,28,30,31,33-$ $36,39,40,42,46,48,50,56,59,61,62,65)$, seven were conducted in postnatal wards of hospitals $(43,45,51,53,58,63,64)$, and two studies were community-based $(25,60)$ (Table 1$)$.

\subsection{Questionnaire and Scales Used in Study}

Questionnaires used in most of studies (7,21,23-33,35-41,4449,51-57,60-62,64,65) are non-standardized questionnaires prepared by researchers based on literature review on subject.

In only nine of examined studies $(4,22,34,42,43,50,58,59,63)$, scale was used. The Breastfeeding Attitude Assessment Scale was used in two studies $(22,34)$, the Breastfeeding Diagnostic Scale (LATCH) $(43,50,58)$ was used in three studies, the BSES-SF $(42,59)$ was used in two studies, and a scale not related to breastfeeding (the Brief Symptom Inventory) and helping to evaluate mothers' psychopathologies was used in two studies $(4,63)$ (Table 1$)$.

\subsection{Results of breastfeeding}

\subsubsection{The time of breastfeeding initiation}

The times of breastfeeding initiation vary in studies reviewed. Accordingly, the time of breastfeeding initiation was indicated to be in the first 30 minutes in 17 studies $(4,26,34$ $36,39,41,44,45,47,48,51,52,54-56,58)$, in the first hour in 19 studies $\quad(22-26,29,30,32,34,35,38,39,41,43,44,47,55,57,65)$, and after the first hour in 19 studies $(22,24,26,32,34,35,38,39,41,44,47,48,50-52,54,55,63,65)$, and the time of breastfeeding initiation was not questioned in 17 studies $(7,21,27,28,31,33,37,40,42,46,49,53,59-62,64)$. Rates of breastfeeding initiation in the first $30 \mathrm{~min}$, first one hour, and after the first hour in studies are presented in Table 2. 
Table 1. Characteristics of the studies reviewed

\begin{tabular}{|c|c|c|c|c|c|}
\hline $\begin{array}{c}\text { Author and Year of } \\
\text { Publication }\end{array}$ & Aim of the Study & $\begin{array}{l}\text { Sample Size Age } \\
\text { Range }\end{array}$ & $\begin{array}{l}\text { Place of the } \\
\text { Study }\end{array}$ & Type of the Study & $\begin{array}{l}\text { Form Used in the } \\
\text { Study }\end{array}$ \\
\hline Can et al. $(2008)^{21}$ & $\begin{array}{l}\text { To evaluate the characteristics of children and } \\
\text { families in Istanbul province }\end{array}$ & \begin{tabular}{|l}
374 people \\
( 9 months- 5 years)
\end{tabular} & \begin{tabular}{|l|} 
Pediatric \\
Polyclinic \\
\end{tabular} & $\begin{array}{l}\text { Descriptive- } \\
\text { Cross-sectional }\end{array}$ & Questionnaire \\
\hline $\begin{array}{l}\text { Gölbaşı and Koç } \\
(2008)^{22}\end{array}$ & $\begin{array}{l}\text { To determine the effect of breastfeeding } \\
\text { behaviors in the first } 6 \text { months postpartum } \\
\text { and attitudes toward breastfeeding during } \\
\text { pregnancy of women in Ankara province on their } \\
\text { breastfeeding behaviors }\end{array}$ & $\begin{array}{l}90 \text { people } \\
\text { (0-6 months) }\end{array}$ & \begin{tabular}{|l|} 
Pregnant women \\
polyclinic and \\
by telephone in \\
the postpartum \\
period
\end{tabular} & $\begin{array}{l}\text { Descriptive- } \\
\text { Cross-sectional }\end{array}$ & $\begin{array}{l}\text { Questionnaire } \\
\text { and } \\
\text { Breastfeeding } \\
\text { Attitude } \\
\text { Assessment Scale } \\
\end{array}$ \\
\hline Ünalan et al. $(2008)^{23}$ & $\begin{array}{l}\text { To examine which variables affect mothers' start } \\
\text { to complementary feedings in a health care } \\
\text { institution in Istanbul province. }\end{array}$ & $\begin{array}{l}358 \text { people } \\
\text { (0-12 months) }\end{array}$ & $\begin{array}{l}\text { Family Health } \\
\text { Center }\end{array}$ & $\begin{array}{l}\text { Descriptive- } \\
\text { Cross-sectional }\end{array}$ & Questionnaire \\
\hline Yıldız et al. $(2008)^{24}$ & $\begin{array}{l}\text { To determine the breastfeeding status of mothers } \\
\text { with 0-11-month-old infants in Ankara province } \\
\text { and the affecting factors }\end{array}$ & $\begin{array}{l}121 \text { people } \\
\text { (0-11 months) }\end{array}$ & $\begin{array}{l}\text { Family Health } \\
\text { Center }\end{array}$ & $\begin{array}{l}\text { Descriptive- } \\
\text { Cross-sectional }\end{array}$ & Questionnaire \\
\hline Yeşildal et al. $(2008)^{25}$ & $\begin{array}{l}\text { To evaluate breastfeeding practices by using } \\
\text { standard breastfeeding indicators in Düzce } \\
\text { province and determine the reasons for the early } \\
\text { cessation of breastfeeding in 0-24-month-old } \\
\text { children in Turkey }\end{array}$ & $\begin{array}{l}158 \text { people } \\
0-24 \text { months }\end{array}$ & Community & Cross-sectional & Questionnaire \\
\hline Gün et al. $(2009)^{26}$ & $\begin{array}{l}\text { To determine the breastfeeding and feeding } \\
\text { status of 0-36-month-old children in Kayseri } \\
\text { province }\end{array}$ & $\begin{array}{l}3038 \text { people } \\
\text { (0-36 months) }\end{array}$ & $\begin{array}{l}\text { Family Health } \\
\text { Center }\end{array}$ & $\begin{array}{l}\text { Descriptive- } \\
\text { Cross-sectional }\end{array}$ & Questionnaire \\
\hline $\begin{array}{l}\text { Kondolot et al. } \\
(2009)^{27}\end{array}$ & $\begin{array}{l}\text { To evaluate the rates of exclusive breastfeeding } \\
\text { in the first six months of healthy infants in Ankara } \\
\text { province and the affecting factors }\end{array}$ & $\begin{array}{l}302 \text { people } \\
\text { (3-24 weeks) }\end{array}$ & $\begin{array}{l}\text { Pediatric } \\
\text { Polyclinic }\end{array}$ & $\begin{array}{l}\text { Descriptive- } \\
\text { Cross-sectional }\end{array}$ & Questionnaire \\
\hline Örün et al. $(2009)^{63}$ & $\begin{array}{l}\text { To investigate the effects of the } \\
\text { psychopathologies and sociodemographic } \\
\text { characteristics of mothers in Ankara province on } \\
\text { breastfeeding within 1-1.5 months postpartum }\end{array}$ & $\begin{array}{l}657 \text { people } \\
\text { (1-1.5 months) }\end{array}$ & $\begin{array}{l}\text { Postpartum } \\
\text { service }\end{array}$ & $\begin{array}{l}\text { Longitudinal } \\
\text { (Prospective) }\end{array}$ & $\begin{array}{l}\text { Brief Symptom } \\
\text { Inventory and } \\
\text { Questionnaire }\end{array}$ \\
\hline Çınar et al. $(2010)^{28}$ & $\begin{array}{l}\text { To determine the effect of mother and infant } \\
\text { sleeping in the same room on breastfeeding in } \\
\text { Sakarya province }\end{array}$ & $\begin{array}{l}254 \text { people } \\
\text { (0-12 months) }\end{array}$ & $\begin{array}{l}\text { Pediatric } \\
\text { Polyclinic }\end{array}$ & $\begin{array}{l}\text { Descriptive- } \\
\text { Cross-sectional }\end{array}$ & Questionnaire \\
\hline $\begin{array}{l}\text { Dolgun and Yüksel } \\
(2010)^{29}\end{array}$ & $\begin{array}{l}\text { To assess the implementation of a breastfeeding } \\
\text { education program for women against the } \\
\text { backdrop of the relevant policies adopted by the } \\
\text { country of Turkey in Istanbul province. }\end{array}$ & $\begin{array}{l}801 \text { people } \\
\text { (0-12 months) }\end{array}$ & $\begin{array}{l}\text { Mother and Child } \\
\text { Care and Family } \\
\text { Planning Center }\end{array}$ & $\begin{array}{l}\text { Descriptive- } \\
\text { Cross-sectional }\end{array}$ & Questionnaire \\
\hline $\begin{array}{l}\text { Gökdemirel et al. } \\
(2010)^{64}\end{array}$ & $\begin{array}{l}\text { It was intended to promote mothers to } \\
\text { exclusively breastfeed their infants for the first } \\
\text { six months by preventing the possible flourishing } \\
\text { problems of breast and breastfeeding in the } \\
\text { early period just after the birth with the help of } \\
\text { counseling and support in Istanbul province. }\end{array}$ & $\begin{array}{l}101 \text { people } \\
0-6 \text { months }\end{array}$ & $\begin{array}{l}\text { Postpartum } \\
\text { service }\end{array}$ & $\begin{array}{l}\text { Longitudinal } \\
\text { (Prospective) }\end{array}$ & Questionnaire \\
\hline İnce et al. $(2010)^{30}$ & $\begin{array}{l}\text { To investigate the reflection of breastfeeding } \\
\text { counseling training on practice by asking } \\
\text { mothers, who applied to the Healthy Child } \\
\text { Polyclinics of two university hospitals in Ankara } \\
\text { and Kayseri, about the status of receiving } \\
\text { breastfeeding counseling }\end{array}$ & $\begin{array}{l}285 \text { people } \\
15-90 \text { days }\end{array}$ & $\begin{array}{l}\text { Healthy Child } \\
\text { Polyclinic }\end{array}$ & \begin{tabular}{|l|} 
Descriptive- \\
Cross-sectional
\end{tabular} & Questionnaire \\
\hline Bolat et al. $(2011)^{65}$ & $\begin{array}{l}\text { To examine the effects of the factors affecting } \\
\text { the time of breastfeeding initiation on exclusive } \\
\text { breastfeeding in the sixth month in Istanbul } \\
\text { province }\end{array}$ & $\begin{array}{l}246 \text { people } \\
\text { (0-6 months) }\end{array}$ & \begin{tabular}{|l} 
Pediatric \\
Polyclinic
\end{tabular} & $\begin{array}{l}\text { Descriptive, } \\
\text { Prospective, } \\
\text { Longitudinal }\end{array}$ & Questionnaire \\
\hline Akova et al. $(2012)^{31}$ & $\begin{array}{l}\text { To determine the effect of breast milk intake on } \\
\text { child development in infants aged 0-36 months in } \\
\text { Istanbul province }\end{array}$ & $\begin{array}{l}100 \text { people } \\
\text { (0-36 months) }\end{array}$ & \begin{tabular}{|l} 
Pediatric \\
Polyclinic
\end{tabular} & $\begin{array}{l}\text { Descriptive- } \\
\text { Cross-sectional }\end{array}$ & Questionnaire \\
\hline Araz $(2012)^{7}$ & $\begin{array}{l}\text { To investigate sociodemographic factors that } \\
\text { may influence the initiation of breastfeeding on } \\
\text { the } 15^{\text {th }} \text { day in the neonatal period in Gaziantep } \\
\text { province }\end{array}$ & $\begin{array}{l}121 \text { people } \\
\text { (15 days) }\end{array}$ & $\begin{array}{l}\text { Pediatric } \\
\text { Polyclinic }\end{array}$ & Retrospective & Questionnaire \\
\hline
\end{tabular}




\begin{tabular}{|c|c|c|c|c|c|}
\hline Çatak et al. $(2012)^{32}$ & $\begin{array}{l}\text { To determine the breastfeeding status and } \\
\text { feeding pattern of mothers in Burdur province }\end{array}$ & $\begin{array}{l}1080 \text { people } \\
\text { (0-18 months) }\end{array}$ & $\begin{array}{l}\text { Family Health } \\
\text { Center }\end{array}$ & $\begin{array}{l}\text { Descriptive- } \\
\text { Cross-sectional }\end{array}$ & Questionnaire \\
\hline $\begin{array}{l}\text { Çeçe and Yenal } \\
(2012)^{33}\end{array}$ & $\begin{array}{l}\text { To determine factors affecting the duration } \\
\text { of breastfeeding of working mothers in Izmir } \\
\text { province }\end{array}$ & $\begin{array}{l}120 \text { people } \\
\text { (12-24 months) }\end{array}$ & $\begin{array}{l}\text { Pediatric } \\
\text { Polyclinic and } \\
\text { Family Health } \\
\text { Center }\end{array}$ & $\begin{array}{l}\text { Descriptive- } \\
\text { Cross-sectional }\end{array}$ & Questionnaire \\
\hline $\begin{array}{l}\text { Kepekçi et al. } \\
(2012)^{61}\end{array}$ & $\begin{array}{l}\text { To examine mothers who apply to a } \\
\text { breastfeeding counseling unit in Istanbul province } \\
\text { and their infants }\end{array}$ & $\begin{array}{l}90 \text { people } \\
\text { (2-300 days) }\end{array}$ & $\begin{array}{l}\text { Breastfeeding } \\
\text { Counseling Unit }\end{array}$ & Retrospective & Questionnaire \\
\hline $\begin{array}{l}\text { Yiğitbaş et al. } \\
(2012)^{34}\end{array}$ & $\begin{array}{l}\text { To determine the behaviors and attitudes of } \\
\text { mothers with regard to breastfeeding in Trabzon } \\
\text { province }\end{array}$ & $\begin{array}{l}405 \text { people } \\
\text { Neonates }\end{array}$ & $\begin{array}{l}\text { Postpartum } \\
\text { service and } \\
\text { Pediatric } \\
\text { polyclinic }\end{array}$ & $\begin{array}{l}\text { Descriptive- } \\
\text { Cross-sectional }\end{array}$ & $\begin{array}{l}\text { Breastfeeding } \\
\text { Attitude } \\
\text { Assessment } \\
\text { Scale and } \\
\text { Questionnaire }\end{array}$ \\
\hline $\begin{array}{l}\text { Sökücü and Aslan } \\
(2012)^{62}\end{array}$ & $\begin{array}{l}\text { To determine the effects of the employment } \\
\text { status on breastfeeding among breastfeeding } \\
\text { mothers in Cyprus }\end{array}$ & $\begin{array}{l}380 \text { people } \\
\text { (6-12 months) }\end{array}$ & $\begin{array}{l}\text { Pediatric } \\
\text { polyclinic }\end{array}$ & Retrospective & Questionnaire \\
\hline $\begin{array}{l}\text { Beşbenli et al. } \\
(2013)^{35}\end{array}$ & $\begin{array}{l}\text { To investigate the information and practices } \\
\text { related to breast milk and nutritional } \\
\text { supplements of mothers living in Istanbul } \\
\text { province and included in three different } \\
\text { socioeconomic groups }\end{array}$ & $\begin{array}{l}202 \text { people } \\
\text { (6-24 months) }\end{array}$ & $\begin{array}{l}\text { Pediatric } \\
\text { polyclinic }\end{array}$ & $\begin{array}{l}\text { Descriptive- } \\
\text { Cross-sectional }\end{array}$ & Questionnaire \\
\hline $\begin{array}{l}\text { Bülbül and Kılınçkaya } \\
(2013)^{36}\end{array}$ & $\begin{array}{l}\text { To investigate the breast milk intake and } \\
\text { breastfeeding status of infants in Kırıkkale } \\
\text { province }\end{array}$ & $\begin{array}{l}94 \text { people } \\
\text { (0-2 years) }\end{array}$ & $\begin{array}{l}\text { Pediatric } \\
\text { polyclinic }\end{array}$ & $\begin{array}{l}\text { Descriptive- } \\
\text { Cross-sectional }\end{array}$ & Questionnaire \\
\hline Sabbağ $(2013)^{37}$ & $\begin{array}{l}\text { To compare the behaviors of mothers with } \\
\text { 0-24-month-old infants in urban and rural areas } \\
\text { in Adıyaman province in child nutrition }\end{array}$ & $\begin{array}{l}103 \text { people } \\
\text { (0-24 months) }\end{array}$ & $\begin{array}{l}\text { Family Health } \\
\text { Center }\end{array}$ & $\begin{array}{l}\text { Descriptive- } \\
\text { Cross-sectional }\end{array}$ & Questionnaire \\
\hline Şahin et al. $(2013)^{38}$ & $\begin{array}{l}\text { To determine the problems faced by mothers } \\
\text { during breastfeeding and risk factors affecting } \\
\text { breastfeeding in Kayseri province }\end{array}$ & $\begin{array}{l}500 \text { people } \\
\text { (24-60 months) }\end{array}$ & $\begin{array}{l}\text { Family Health } \\
\text { Center }\end{array}$ & $\begin{array}{l}\text { Descriptive- } \\
\text { Cross-sectional }\end{array}$ & Questionnaire \\
\hline Yenal et al. $(2013)^{39}$ & $\begin{array}{l}\text { To investigate the relationship between the } \\
\text { breastfeeding self-efficacy perception and } \\
\text { breastfeeding success of mothers in the postnatal } \\
\text { period in Izmir province }\end{array}$ & $\begin{array}{l}220 \text { people } \\
\text { (Neonates) }\end{array}$ & $\begin{array}{l}\text { Pediatric } \\
\text { polyclinic }\end{array}$ & $\begin{array}{l}\text { Descriptive- } \\
\text { Cross-sectional }\end{array}$ & Questionnaire \\
\hline Şencan et al. $(2013)^{40}$ & $\begin{array}{l}\text { To investigate factors affecting the duration of } \\
\text { breastfeeding in Ankara province }\end{array}$ & 2-4 years & $\begin{array}{l}\text { Pediatric } \\
\text { polyclinic }\end{array}$ & $\begin{array}{l}\text { Descriptive- } \\
\text { Cross-sectional }\end{array}$ & Questionnaire \\
\hline Sivri et al. $(2014)^{41}$ & $\begin{array}{l}\text { To determine the duration and causes of the } \\
\text { transition to complementary feeding among } \\
\text { mothers with 0-6-month-old infants in Konya } \\
\text { province }\end{array}$ & $\begin{array}{l}220 \text { people } \\
\text { (0-6 months) }\end{array}$ & $\begin{array}{l}\text { Family Health } \\
\text { Center }\end{array}$ & $\begin{array}{l}\text { Descriptive- } \\
\text { Cross-sectional }\end{array}$ & Questionnaire \\
\hline Çınar et al. $(2014)^{42}$ & $\begin{array}{l}\text { To determine breastfeeding self-efficacy and } \\
\text { factors affecting it among mothers during the } \\
\text { 0-3-month period in Sakarya province }\end{array}$ & $\begin{array}{l}152 \text { people } \\
0-3 \text { months }\end{array}$ & $\begin{array}{l}\text { Pediatric } \\
\text { polyclinic and } \\
\text { Family Health } \\
\text { Center }\end{array}$ & $\begin{array}{l}\text { Descriptive- } \\
\text { Cross-sectional }\end{array}$ & $\begin{array}{l}\text { Questionnaire } \\
\text { Breastfeeding } \\
\text { Self-Efficacy } \\
\text { Scale-Short Form } \\
\text { / BSES-SF } \\
\end{array}$ \\
\hline $\begin{array}{l}\text { Bostancı and İnal } \\
(2015)^{43}\end{array}$ & $\begin{array}{l}\text { To determine the level of knowledge about } \\
\text { breastfeeding and breastfeeding status of } \\
\text { mothers who gave birth in a private hospital in } \\
\text { Istanbul province }\end{array}$ & $\begin{array}{l}150 \text { people } \\
\text { (Neonates) }\end{array}$ & $\begin{array}{l}\text { Postpartum } \\
\text { service }\end{array}$ & $\begin{array}{l}\text { Descriptive- } \\
\text { Cross-sectional }\end{array}$ & $\begin{array}{l}\text { Breastfeeding } \\
\text { Diagnostic } \\
\text { Measurement } \\
\text { Tool (LATCH) and } \\
\text { Questionnaire } \\
\end{array}$ \\
\hline Dinç et al. $(2015)^{44}$ & $\begin{array}{l}\text { To determine traditional practices with regard to } \\
\text { breastfeeding and breast milk of mothers with } \\
6 \text {-18-month-old infants in Çanakkale province }\end{array}$ & $\begin{array}{l}212 \text { people } \\
\text { (6-18 months) }\end{array}$ & $\begin{array}{l}\text { Family Health } \\
\text { Center }\end{array}$ & $\begin{array}{l}\text { Descriptive- } \\
\text { Cross-sectional }\end{array}$ & Questionnaire \\
\hline Demirtaş $(2015)^{45}$ & $\begin{array}{l}\text { To describe the informative, practical and } \\
\text { emotional support received by multiparous } \\
\text { mothers in the early postnatal period from nurses } \\
\text { in Ankara province }\end{array}$ & $\begin{array}{l}278 \text { people } \\
\text { Neonates }\end{array}$ & $\begin{array}{l}\text { Postpartum } \\
\text { service }\end{array}$ & $\begin{array}{l}\text { Descriptive- } \\
\text { Cross-sectional }\end{array}$ & Questionnaire \\
\hline
\end{tabular}




\begin{tabular}{|c|c|c|c|c|c|}
\hline $\begin{array}{l}\text { Erkuran et al. } \\
(2015)^{46}\end{array}$ & $\begin{array}{l}\text { To determine the frequency of exclusive } \\
\text { breastfeeding and to examine the affecting } \\
\text { factors among infants applying to a pediatric } \\
\text { polyclinic in Ankara province }\end{array}$ & $\begin{array}{l}603 \text { people } \\
6-24 \text { months }\end{array}$ & $\begin{array}{l}\text { Pediatric } \\
\text { polyclinic }\end{array}$ & $\begin{array}{l}\text { Descriptive- } \\
\text { Cross-sectional }\end{array}$ & Questionnaire \\
\hline $\begin{array}{l}\text { Karadağ et al. } \\
(2016)^{47}\end{array}$ & $\begin{array}{l}\text { To determine breastfeeding characteristics of } \\
\text { mothers with infants younger than } 6 \text { months in } \\
\text { Bursa province }\end{array}$ & $\begin{array}{l}186 \text { people } \\
\text { (0-6 months) }\end{array}$ & $\begin{array}{l}\text { Family Health } \\
\text { Center }\end{array}$ & $\begin{array}{l}\text { Descriptive- } \\
\text { Cross-sectional }\end{array}$ & Questionnaire \\
\hline Çalık et al. $(2017)^{48}$ & $\begin{array}{l}\text { To determine breastfeeding practices and } \\
\text { affecting factors of mothers with 6-24-month-old } \\
\text { infants in Trabzon province }\end{array}$ & $\begin{array}{l}401 \text { people } \\
\text { (6-24 months) }\end{array}$ & $\begin{array}{l}\text { Pediatric } \\
\text { polyclinic }\end{array}$ & $\begin{array}{l}\text { Descriptive- } \\
\text { Cross-sectional }\end{array}$ & Questionnaire \\
\hline $\begin{array}{l}\text { Gümüştakım et al. } \\
(2017)^{49}\end{array}$ & $\begin{array}{l}\text { To evaluate the nutritional habits of 0-2-year-old } \\
\text { children and their mothers' levels of knowledge } \\
\text { about nutrition in } 5 \text { different provinces (Sakarya, } \\
\text { Hatay, Karaman, Ordu, Rize) }\end{array}$ & $\begin{array}{l}250 \text { people } \\
\text { ( } 0-2 \text { years) }\end{array}$ & $\begin{array}{l}\text { Family Health } \\
\text { Center }\end{array}$ & $\begin{array}{l}\text { Descriptive- } \\
\text { Cross-sectional }\end{array}$ & Questionnaire \\
\hline İnce et al. $(2017)^{50}$ & $\begin{array}{l}\text { To evaluate breastfeeding self-efficacy and } \\
\text { characteristics affecting breastfeeding success of } \\
\text { mothers in Izmir province }\end{array}$ & $\begin{array}{l}91 \text { people } \\
\text { (Neonates) }\end{array}$ & $\begin{array}{l}\text { Pediatric } \\
\text { polyclinic }\end{array}$ & $\begin{array}{l}\text { Descriptive- } \\
\text { Cross-sectional }\end{array}$ & $\begin{array}{l}\text { Breastfeeding } \\
\text { Self-Efficacy } \\
\text { Scale-Short Form, } \\
\text { Breastfeeding } \\
\text { Diagnostic and } \\
\text { Assessment Scale } \\
\text { (LATCH) and } \\
\text { Questionnaire } \\
\end{array}$ \\
\hline Koç et al. $(2017)^{51}$ & $\begin{array}{l}\text { To evaluate the knowledge, opinions, and } \\
\text { attitudes of mothers in Erzurum province with } \\
\text { regard to breastfeeding coaching }\end{array}$ & $\begin{array}{l}275 \text { people } \\
\text { (Neonates) }\end{array}$ & $\begin{array}{l}\text { Postpartum } \\
\text { service }\end{array}$ & $\begin{array}{l}\text { Descriptive- } \\
\text { Cross-sectional }\end{array}$ & Questionnaire \\
\hline $\begin{array}{l}\text { Şahin and Özyurt } \\
(2017)^{52}\end{array}$ & $\begin{array}{l}\text { To evaluate the breastfeeding status and } \\
\text { nutritional habits of 0-24-month-old infants in } \\
\text { Manisa province }\end{array}$ & $\begin{array}{l}140 \text { people } \\
\text { (0-24 months) }\end{array}$ & $\begin{array}{l}\text { Family Health } \\
\text { Center }\end{array}$ & $\begin{array}{l}\text { Descriptive- } \\
\text { Cross-sectional }\end{array}$ & Questionnaire \\
\hline Yılmaz et al. $(2017)^{53}$ & $\begin{array}{l}\text { To determine the time of the first breastfeeding, } \\
\text { the rates of exclusive breastfeeding in the first six } \\
\text { months of life, and factors affecting the feeding } \\
\text { practices of infants of mothers, who gave birth in } \\
\text { a baby-friendly hospital in Ankara province } \\
\end{array}$ & $\begin{array}{l}350 \text { people } \\
0-6 \text { months }\end{array}$ & \begin{tabular}{|l|} 
Postpartum \\
service and by \\
telephone after 6 \\
months
\end{tabular} & $\begin{array}{l}\text { Descriptive- } \\
\text { Cross-sectional }\end{array}$ & Questionnaire \\
\hline Canbay $(2018)^{54}$ & $\begin{array}{l}\text { To examine the ways of feeding of infants born } \\
\text { by cesarean section in Aydın province in the first } \\
\text { six months }\end{array}$ & $\begin{array}{l}152 \text { people } \\
\text { (7-12 months) }\end{array}$ & $\begin{array}{l}\text { Family Health } \\
\text { Center }\end{array}$ & $\begin{array}{l}\text { Descriptive- } \\
\text { Cross-sectional }\end{array}$ & Questionnaire \\
\hline $\begin{array}{l}\text { Derin and Erdoğan } \\
(2018)^{55}\end{array}$ & $\begin{array}{l}\text { To determine breastfeeding practices of mothers } \\
\text { with 0-24-month-old infants in Muş province }\end{array}$ & \begin{tabular}{|l}
508 people \\
(0-24 months)
\end{tabular} & $\begin{array}{l}\text { Family Health } \\
\text { Center }\end{array}$ & \begin{tabular}{|l|} 
Descriptive- \\
Cross-sectional
\end{tabular} & Questionnaire \\
\hline $\begin{array}{l}\text { KırıCı and Görak } \\
(2018)^{56}\end{array}$ & $\begin{array}{l}\text { To evaluate the nutritional status and affecting } \\
\text { factors of mothers with } 0-6 \text {-month-old infants in } \\
\text { Karaman province }\end{array}$ & $\begin{array}{l}200 \text { people } \\
\text { (0-6 months) }\end{array}$ & $\begin{array}{l}\text { Pediatric } \\
\text { polyclinic }\end{array}$ & $\begin{array}{l}\text { Descriptive- } \\
\text { Cross-sectional }\end{array}$ & Questionnaire \\
\hline Göl $(2018)^{57}$ & $\begin{array}{l}\text { To evaluate the effect of the status of receiving } \\
\text { prenatal care on breastfeeding behaviors of } \\
\text { mothers with 0-24-month-old infants who apply } \\
\text { to family health centers in Çankırı province }\end{array}$ & $\begin{array}{l}141 \text { people } \\
0-24 \text { months }\end{array}$ & $\begin{array}{l}\text { Family Health } \\
\text { Center }\end{array}$ & $\begin{array}{l}\text { Descriptive- } \\
\text { Cross-sectional }\end{array}$ & Questionnaire \\
\hline $\begin{array}{l}\text { Keloğlan et al. } \\
(2018)^{58}\end{array}$ & $\begin{array}{l}\text { To investigate factors affecting the breastfeeding } \\
\text { status of postpartum mothers in Amasya province }\end{array}$ & \begin{tabular}{|l|l}
51 people \\
neonates
\end{tabular} & $\begin{array}{l}\text { Postpartum } \\
\text { service }\end{array}$ & \begin{tabular}{|l|} 
Descriptive- \\
Cross-sectional \\
\end{tabular} & LATCH \\
\hline $\begin{array}{l}\text { Küçükkaya et al. } \\
(2018)^{59}\end{array}$ & $\begin{array}{l}\text { To investigate the relationship between } \\
\text { breastfeeding self-efficacy and the time of } \\
\text { transition to supplementary feeding of mothers } \\
\text { in Edirne province }\end{array}$ & $\begin{array}{l}282 \text { people } \\
0-2 \text { years }\end{array}$ & $\begin{array}{l}\text { Pediatric } \\
\text { polyclinic }\end{array}$ & $\begin{array}{l}\text { Descriptive- } \\
\text { Cross-sectional }\end{array}$ & $\begin{array}{l}\text { Questionnaire } \\
\text { Breastfeeding } \\
\text { Self- } \\
\text { Efficacy Scale } \\
\end{array}$ \\
\hline Salcan et al. $(2018)^{60}$ & $\begin{array}{l}\text { To investigate the frequency of exclusive } \\
\text { breastfeeding during the first six months and } \\
\text { factors affecting this in infants born in } 2016 \text { in } \\
\text { Erzincan province }\end{array}$ & $\begin{array}{l}635 \text { people } \\
0-2 \text { years }\end{array}$ & $\begin{array}{l}\text { Family practice } \\
\text { Community }\end{array}$ & $\begin{array}{l}\text { Descriptive- } \\
\text { Cross-sectional }\end{array}$ & Questionnaire \\
\hline $\begin{array}{l}\text { Yüzügüllü et al. } \\
(2018)^{4}\end{array}$ & $\begin{array}{l}\text { To investigate sociodemographic characteristics } \\
\text { and psychopathological characteristics of } \\
\text { mothers living in Adana province and to } \\
\text { investigate the effects of these characteristics on } \\
\text { the status of exclusive breastfeeding in the first } \\
\text { six months }\end{array}$ & $\begin{array}{l}284 \text { people } \\
6-12 \text { months }\end{array}$ & $\begin{array}{l}\text { Family Health } \\
\text { Center }\end{array}$ & $\begin{array}{l}\text { Descriptive- } \\
\text { Cross-sectional }\end{array}$ & $\begin{array}{l}\text { Questionnaire } \\
\text { Symptom Check } \\
\text { List (SCL-90-R) }\end{array}$ \\
\hline
\end{tabular}




\subsubsection{Duration of breastfeeding, exclusively breastfeeding and total breastfeeding}

In studies examined, mean duration of breastfeeding was $(7,26,29,31-33,38-41,44,52,53,59,60)$ minimum 3.45 months and maximum 17.7 months, the time of starting complementary feeding $(24,29,31,38,53,58,59)$ was minimum 2.04 months on average and maximum 6 months, and ratio of exclusive breastfeeding in the first 6 months $(4,21,26,29,38,46,48,52,53,57-60,64)$ was minimum $8.7 \%$ and maximum $67.1 \%$. In 23 studies, duration of exclusive breastfeeding was not indicated (Table 3 ).

\subsubsection{Breastfeeding-related factors}

Upon examining breastfeeding-related factors in study, it was determined that maternal age $(46,48,58,59)$, educational level $(4,25,33,34,48,52,53,55,59,60)$, employment status $(4,34,40,48,60,62,63)$, and economic status $(33,38,63)$ were frequently effective in terms of demographic variables; parity and number of living children $(29,30,33,38,39,58,59,63,65)$, type of birth $(22,23,25,29,30,38,52,53,57)$ and preterm birth $(23,27,36,59,64,65)$ were frequently effective in terms of obstetric variables; and status of receiving information on breastfeeding $(4,29,42,48,53,57,60,65)$, having breastfeeding experience $(22,42,50,58)$, early postnatal breastfeeding $(4,38,55,58,59,65)$, giving complementary feeding or formula $(23,25,46,55,59,60)$, and use of a pacifier or a feeding bottle were frequently effective in terms of breastfeeding-related variables $(23,27,53,60)$ (Table 4).

In studies examined, it was determined that an increase in number of children, having a vaginal birth, having received education on breastfeeding, and initiating early postnatal breastfeeding affected breastfeeding positively. Advanced maternal age, high educational level, working mother, good economic status, preterm birth, giving complementary feeding or formula, and use of a pacifier or feeding bottle were observed to have adverse effects on breastfeeding.

\subsubsection{Reasons for starting complementary feeding}

Upon examining reasons for starting complementary feeding in examined studies, the most common reasons were determined as insufficient breast milk or cessation of breastfeeding $(4,25,29,32,40,41,44,45,46,48,53,55,60)$, the fact that infant does not suck $(25,32,37,44,45,48)$, and mother's thinking that child has grown up and it is time to wean $(4,41,44,53,60)$. The other reasons were determined to be mother's and infant's disease $(25,44)$, experiencing a breastfeeding problem (45), starting to work (4), getting used to a feeding bottle (44), and low self-efficacy (58). In the other 32 studies (7,21-24,26-28,30,31,33-36,38,39,42,43,47,49$52,54,56,57,59,61-65)$, no data on this variable could be found (Table 5).

Table 2. The times of breastfeeding initiation

\begin{tabular}{|l|l|l|}
\hline \multicolumn{1}{|c|}{ Breastfeeding Times } & \multicolumn{1}{|c|}{ The Number of Studies } & \multicolumn{1}{c|}{ Minimum-Maximum } \\
\hline The first 30 minutes & 17 studies $^{4,26,34-36,39,41,44,45,47,48,51,52,54-56,58}$ & $12.4 \%-93.7 \%$ \\
\hline The first 1 hour & 19 studies $^{22-26,29,30,32,34,35,38,39,41,43,44,47,55,57,65}$ & $9.9 \%-92.4 \%$ \\
\hline After 1 hour & 19 studies $^{22,24,26,32,34,35,38,39,41,44,47,48,50-52,54,55,63,65}$ & $12 \%-100 \%$ \\
\hline Not specified & 17 studies $^{7,21,27,28,31,33,37,40,42,46,49,53,59,60-62,64}$ & Non applicable \\
\hline
\end{tabular}

Table 3. Data on the duration of breastfeeding*

\begin{tabular}{|l|l|l|}
\hline & \multicolumn{1}{|c|}{ The Number of Studies } & \multicolumn{1}{c|}{ Min-Max (Mean) } \\
\hline The Mean Duration of Breastfeeding & 15 studies $^{7,26,29,31-33,38-41,44,52,53,59,60}$ & $3.45-17.7$ months \\
\hline The Time of Starting Complementary Feeding & 7 studies $^{24,29,31,52,53,58,59}$ & $2.04-6$ months \\
\hline & & Min - Max (\%) \\
\hline $\begin{array}{l}\text { Exclusive Breastfeeding in the First 6 Months } \\
\text { The duration of exclusive breastfeeding was not } \\
\text { specified }\end{array}$ & 14 studies $^{4,21,26,29,38,46,48,52,53,57-60,64}$ & $8.7-67.1$ \\
\hline
\end{tabular}

*In one study, there may be more than one data on the duration of breastfeeding. 
Table 4. Breastfeeding-related factors

\begin{tabular}{|c|c|c|}
\hline Sociodemographic & Obstetric & Breastfeeding \\
\hline Maternal age $\mathrm{e}^{46,48,58,59}$ & Parity/number of living children $29,30,33,37,38,58,59,63,65$ & $\begin{array}{l}\text { Receiving professional support on breastfeeding by } \\
\text { the mother }{ }^{4,29,42,48,53,57,60,65}\end{array}$ \\
\hline Mother's educational level $4,25,33,34,48,52,53,55,59,60$ & Type of birth $22,23,25,29,30,38,52,53,57$ & $\begin{array}{l}\text { The status of breastfeeding the previous infant / } \\
\text { Having a positive breastfeeding experience }{ }^{22,42,50,58}\end{array}$ \\
\hline Employment status $4,34,40,48,60,62,63$ & Premature birth/ Premature infant ${ }^{23,27,36,59,64,65}$ & $\begin{array}{l}\text { First breastfeeding time/ Early postnatal } \\
\text { breastfeeding } \text { b } 38,55,58,59,65^{\text {b }}\end{array}$ \\
\hline Economic status ${ }^{33,38,63}$ & Willing pregnancy $\mathrm{y}^{22,53,63}$ & Giving complementary feeding/formula $23,25,46,55,59,60$ \\
\hline Living in rural/urban areas ${ }^{25,59}$ & The frequency of pregnant follow-up ${ }^{48}$ & The use of a pacifier/feeding bottle $\mathrm{e}^{23,27,53,60}$ \\
\hline Family type ${ }^{48}$ & Birth weight ${ }^{38}$ & The concern about insufficient milk secretion ${ }^{38}$ \\
\hline Smoking ${ }^{63}$ & Infant's gender 25,33 & The number of daily breastfeeding ${ }^{38}$ \\
\hline \multirow[t]{9}{*}{ Medical problems ${ }^{22,46}$} & & Weak sucking reflex ${ }^{22}$ \\
\hline & & The frequency of breastfeeding ${ }^{55}$ \\
\hline & & The suitability of breastfeeding conditions at work ${ }^{33}$ \\
\hline & & Breast problem ${ }^{38,58}$ \\
\hline & & The status of exclusive breastfeeding ${ }^{50}$ \\
\hline & & Postnatal stay of the infant in the neonatal unit ${ }^{22}$ \\
\hline & & The status of taking colostrum 55,58 \\
\hline & & The status of receiving social support ${ }^{33,53}$ \\
\hline & & Sharing the same room with the infant $\mathrm{t}^{40,59}$ \\
\hline
\end{tabular}

Table 5. The reasons for starting complementary feeding**

\begin{tabular}{|l|l|}
\hline The thought that breast milk is insufficient & The Number of Studies \\
\hline The fact that the infant does not suck & 13 studies $^{4,25,29,32,40,41,44-46,48,53,55,60}$ \\
\hline $\begin{array}{l}\text { Thinking that the child has grown up or the time to wean from breast has } \\
\text { come }\end{array}$ & 6 studies $^{25,32,37,44,45,48}$ \\
\hline Disease of the mother or infant & studies \\
\hline Experi,44,53,60 \\
\hline Starting to work & 2 studies $^{25,44}$ \\
\hline Getting used to a feeding bottle & 1 study $^{45}$ \\
\hline Low self-efficacy & 1 study $^{4}$ \\
\hline Studies without data on this subject & 1 study $^{44}$ \\
\hline
\end{tabular}

**There may be more than one reason in one study.

\section{DISCUSSION}

The present study was carried out to systematically review studies conducted on breastfeeding in Turkey and to provide information on breastfeeding status, and the time of breastfeeding initiation and duration of breastfeeding. Factors affecting breastfeeding, and reasons for starting complementary feeding in Turkey were also determined within scope of study.

International organizations recommend that mothers should start breastfeeding their infants within the first hour after birth because it is important to support initiation of breastfeeding within the first hour in terms of maternal and neonatal health. Among studies evaluated within scope of this systematic review, ratios of breastfeeding initiation in the first hour are quite different from each other, and there is no consistency between studies. Similarly, in literature, Silva et al. (2018) (9), Smith et al. (2015) (66), and Kushwaha et al. (2018) (67) indicate different ratios in their studies in terms of ratios of breastfeeding initiation in the first hour. This can be interpreted as the fact that ratios of breastfeeding initiation in the first hour can be affected by many factors, and this can be due to different sample groups for each study. The fact that reasons for not breastfeeding within the first hour were included in very few studies in this review led to conclusion that this subject should be investigated in future studies. Determining factors that increase and decrease initiation of breastfeeding within the first hour may contribute to increasing breastfeeding within the first hour. 
The most important characteristic of the first years of life is rapid growth and development. During this period, infant should be breastfed and receive breast milk sufficiently. In Turkey, $41 \%$ of infants younger than 6 months are exclusively breastfed. These results are similar to world data (40\%). However, it is observed that ratio of exclusively breastfed infants rapidly decreases from the first month and decreases to $14 \%$ in $4-5$-month-old infants $(2,6)$. This shows that reasons for the rapid regression of breastfeeding in the early period should be investigated, and effective solutions should be put forward. Mean duration of breastfeeding varies among studies in this review. It was determined that goal of exclusive breastfeeding in the first six months and breastfeeding until two years of age could not be mostly achieved in Turkey. It is observed that in studies by Bai et al. (2015) (68), Cox et al. (2015) (69), and Nelson et al. (2018) (13), these goals could not be achieved, similarly to result of present study. This can be considered as an indication that goal of exclusive breastfeeding in the first six months and breastfeeding until two years of age could not be reached despite the longterm strategies to support breastfeeding worldwide. These results suggest that strategies and practices for initiating and sustaining breastfeeding should be reviewed and studies should be carried out to determine difficulties in practice.

Within scope of current systematic review, it was detected that breastfeeding is affected by many factors in studies examined. In this section, breastfeeding-related variables in publications examined within scope of review were discussed under demographic, obstetric, and breastfeeding-related sub-headings.

Maternal age was among variables affecting breastfeeding in the current review. Breastfeeding was observed to be negatively affected with increasing maternal age. In literature, there are studies supporting the fact that advanced maternal age affects breastfeeding negatively (13), not supporting this fact $(66)$, and indicating that they are not related $(10,14,70)$. In this review and in literature, it is still not possible to reach a conclusion about age and breastfeeding. It is thought that further studies are needed.

Educational level is another variable that affects breastfeeding. According to result of this review, it was determined that breastfeeding was adversely affected as educational level increased. In literature, there are studies supporting the fact that increase in educational level affects breastfeeding adversely $(10,11)$, not supporting this fact $(66,70)$, and stating that they are not related (14). Effect of educational level on breastfeeding has not been revealed yet. However, this variable should be evaluated together with employment status, not alone because women with high educational level are usually active in working life. In other words, it can be thought that educational level affects breastfeeding indirectly, not directly. Research on this subject is needed.

In this review, it was detected that breastfeeding status of working mothers was negatively affected. In literature, there are studies supporting negative effect of employment status on breastfeeding $(15,66,69,71)$ and indicating that they are not related (14). However, no study that did not support this result was encountered. This suggests that working mothers need strategies to help them continue breastfeeding. Also economic status was identified as an other variable that affects breastfeeding in the present study.

Breastfeeding was observed to be adversely affected as the income increased. This can be interpreted as the fact that ease of accessing formula by individuals with good economic status may affect breastfeeding adversely. In literature, there are studies supporting negative effect of increase in economic status on breastfeeding $(11,72)$, not supporting this $(70)$ and stating that they are not related (14). It is thought that more studies on effect of economic status are needed.

Among reviewed publications, breastfeeding status in rural and urban areas was included only in two studies. While the duration of breastfeeding was found to be longer in the rural area in comparison with urban area in one of them, it was observed that complementary feeding was given earlier in rural area in the other study. No data on this variable were found in literature. There is a need for further studies on this subject.

Smoking emerged as a factor affecting breastfeeding in one of publications examined in this review. Upon reviewing literature, there are studies stating that smoking affects breastfeeding adversely $(13,69,70,73)$. It is observed that breastfeeding is negatively affected by a replaceable factor, such as smoking. Therefore, it is thought that quitting smoking during pregnancy will contribute positively to breastfeeding.

Two of publications reported that medical reasons of mother and infant affected breastfeeding adversely in the current review. In literature, there are studies indicating that medical reasons of mother and infant affect breastfeeding adversely (66) and indicating that they are not related (70). There is a need for more studies to reach a conclusion with regard to this variable. Also, no data on body mass index (BMI) and breastfeeding were found in any of publications in the present review. However, there are studies in literature supporting the fact that obesity affects breastfeeding adversely in relation to this variable $(13,69,73)$ and indicating that it does not affect breastfeeding (66). It is thought that developing strategies to reduce prenatal BMI will affect breastfeeding positively and will not have a negative effect.

Parity and number of living children is one of the most common obstetric variables related to breastfeeding in this review. Increase in parity and number of living children was observed to affect breastfeeding positively. There are studies in literature supporting the fact that increase in number of children affects breastfeeding positively $(10,13,73)$. This situation suggests that primiparous mothers should be supported more.

Type of birth is another variable most frequently associated with breastfeeding in this review. Breastfeeding was determined to be positively affected in vaginal delivery group. In study conducted by Kronborg et al. (2018) (10) in Denmark, 
durations of exclusive breastfeeding and breastfeeding were found to be longer in non-cesarean mothers. Result obtained by Kronborg et al. (2018) (10) and result of this review are similar to each other. Supporting vaginal delivery can be recommended as a variable that affects breastfeeding positively. However, it was determined that preterm birth affected breastfeeding negatively in the present review. In literature, there are studies that support (10) and do not support this result (66). Difference between this review and study by Smith et al. (2015) (66) may be due to the fact that studies were conducted in different countries.

In this review, a willing pregnancy was included in three publications as a variable that affects breastfeeding. No data on positive or negative effects of it on breastfeeding were found in these publications. Furthermore, no data on this variable were found in literature. Data on gender of infant were found in two publications in the current review. In one of these publications, it was determined that male infants were breastfed longer. In study conducted in Denmark, Kronborg et al. (2018) (10) found that gender was not related to duration of breastfeeding. In study carried out by Stough et al. (2018) (70) in the USA, no relationship between infant's gender and breastfeeding was found.

Receiving professional support on breastfeeding is one of the most common variables that affect breastfeeding in this review. Receiving education on breastfeeding was determined to affect breastfeeding positively. In literature, there are studies supporting this result $(10,14,15,73)$. Achieving a similar result with literature revealed necessity of providing professional support on breastfeeding to women. In addition, it was determined that having breastfeeding experience affected breastfeeding positively in the present review. In literature, there are studies supporting this result $(10,68)$. This suggests that primiparous women and women without previous breastfeeding experience should be supported.

Early breastfeeding in postpartum is another variable that is prominent in publications examined in this review. Early breastfeeding in postpartum was found to affect breastfeeding positively. In study conducted in the USA, Perrine et al. (2012) (73) reported that initiating breastfeeding within the first hour had a positive effect on breastfeeding. The early initiation of breastfeeding is thought to be a factor that affects breastfeeding positively. Recommendations of the WHO and UNICEF are also in line with this.

In this review, it was determined that giving complementary feeding or formula affected breastfeeding adversely. There are studies in literature supporting this result $(10,11,15,73,74)$. These results suggest that effective counseling should be provided in postpartum period and it should be ensured that mothers exclusively breastfeed and complementary feeding or formula is not given in hospital. Moreover, in publications examined in this review, use of a pacifier or feeding bottle is another variable that affects breastfeeding. The use of a pacifier or feeding bottle was found to affect breastfeeding adversely. Bottle-feeding is common in Turkey. According to the TDHS 2018 data, 53\% of all 0-23-month-old children are fed with a feeding bottle (6). In literature, there are studies stating that use of a feeding bottle affects breastfeeding $(9,73)$. Mothers should be informed about adverse effects of use of a feeding bottle on breastfeeding.

In publications examined in the current review, variables such as the concern of insufficient milk secretion, daily number of breastfeeding sessions, poor sucking reflex, breastfeeding frequency, suitability of breastfeeding conditions at work, experiencing breast problems, status of exclusive breastfeeding, status of taking colostrum, status of infant's staying in postpartum neonatal unit, receiving social support, father's breastfeeding support, and sharing same room with infant were reported as rare factors affecting breastfeeding. There is a need for more studies on positive or negative effects of all these variables on breastfeeding.

The most common reason for starting complementary feeding in this review was stated as insufficiency/cessation of breastfeeding/absence of breast milk. In literature, there are studies supporting this result $(15,75)$. Mothers' concerns about whether their milk is sufficient or not should be eliminated, and they should be informed on this subject. Therefore, it is thought that rates of starting complementary feeding in the early period will decrease, if there is no need for it (except for indications). Moreover, non-sucking of infant was among reasons for starting complementary feeding in current review. It is striking that there are no data on this variable upon reviewing literature. This variable is based on statements of mothers. It is necessary to investigate whether this subjective evaluation made by mothers is related to objective data (appropriate position, etc.), to determine and solve problem. Thinking that child has grown up or the time to wean from breast has come is another variable among reasons for starting complementary feeding in this review. However, when reviewed studies are examined, age ranges of infants (min: 0 months, max: 24 months) differ. Therefore, no clear data on the month when complementary feeding was started could be obtained. Thinking that the time to wean from breast has come and starting complementary feeding are parallel to result of the prospective study by Susiloretni et al. (2019) (75) in which mothers and her infants were followed up for 26 months. In addition, in this review, diseases of mother and infant was indicated as reason for starting complementary feeding in two studies. In literature, there are studies supporting the fact that this variable is among reasons for starting complementary feeding $(15,74)$. In this case, breastfeeding should be supported more by health care professionals in presence of medical reasons.

Experiencing a breastfeeding problem was stated as reason for starting complementary feeding only in one study in this review. In literature, there are studies supporting idea that this variable is among reasons for starting complementary feeding $(14,15,74)$. It is thought that elimination and prevention of breastfeeding problems will positively affect breastfeeding of infant. Getting used to a feeding bottle was indicated as reason for starting complementary feeding in 
only one study in this review. WHO does not recommend using a bottle to support breastfeeding $(2,3)$.

Starting to work was indicated as reason for stopping breastfeeding in only one study in the current review. Present study is parallel to study by O'conner et al. (2018) (74) in terms of this variable. Mothers who breastfeed need necessary arrangements to maintain breastfeeding when they start to work. Low self-efficacy was among reasons for stopping breastfeeding in only one study in this review. Sun et al. (2017) (15) found in their study that women with lower self-efficacy quitted breastfeeding more frequently. We think that more studies are required on this subject and women's self-efficacy on breastfeeding should be increased.

In literature, desire for breastfeeding $(15,74)$, confidence in breastfeeding and mother-friendly hospital practices, lack of mother's plan on exclusive breastfeeding (14), and low postpartum support (74) were found to be associated with weaning from breast. It was determined that all these variables were not indicated as reasons in studies examined in current review. There is a need for future studies to investigate these variables.

\section{Limitations}

This systematic review has some limitations. These are as follows:

The use of different and non-standard data collection forms in studies reviewed, experiencing difficulties with interpretation of data on breastfeeding (the time of breastfeeding initiation, the duration of breastfeeding, etc.),

- The inclusion of only publications the full text of which could be reached,

- Different sample sizes and the heterogeneous structure of age groups,

- The fact that most of study data are based on personal statements.

Still, the fact that most of the studies included the time of breastfeeding initiation, duration of breastfeeding, breastfeeding-related factors, and reasons for starting complementary feeding made a significant contribution in terms of creating an idea about the status of breastfeeding in Turkey.

\section{CONCLUSION}

This systematic review was reported using the PRISMA checklist (http://www.prisma-statement.org/) in order to systematically review studies conducted on breastfeeding in Turkey and to provide information on breastfeeding status. At the end of this reporting, it was determined that studies conducted on breastfeeding in our country had common goals, but there was no unity of language and definition. Studies were conducted with different time intervals, sample sizes, and age ranges. Despite these difficulties, results show important conclusions about national breastfeeding status.

The time to start breastfeeding can be stated as half an hour in 17 studies and 1 hour in 19 studies. In studies examined, mean duration of breastfeeding was minimum 3.45 months and maximum 17.7 months. And ratio of exclusive breastfeeding in the first 6 months was minimum $8.7 \%$ and maximum $67.1 \%$. It was determined that ratio of initiating breastfeeding and mean duration of breastfeeding varied significantly in our country and breastfeeding was mostly influenced by educational level of mother. The most common reason for starting complementary feeding was found to be thought that breast milk was insufficient.

\section{Ethical approval}

Not applicable. As this paper presents findings of an integrative literature review of published articles ethical approval was not required.

\section{Acknowledgements}

No assistance or funding was received to undertake this integrative literature review.

\section{Conflicts of interest}

The authors have no conflicts of interest to declare.

\section{REFERENCES}

[1] WHO Breastfeeding 2019. Available at http://www.who.int/ topics/breastfeeding/en/ (accessed 6.11.2019)

[2] WHO Ten facts on breastfeeding 2019. Available at https:// www.who.int/features/factfiles/breastfeeding/en/ (accessed 6.11.2019)

[3] WHO Maternal, newborn, child and adolescent health 2019. Available at https://www.who.int/maternal_child_ adolescent/topics/child/nutrition/breastfeeding/en/ (accessed 02.11.2019)

[4] Yüzügüllü DA, Aytaç N, Akbaba M. Investigation of the factors affecting mother's exclusive breastfeeding for six months. Turk Pediatri Ars 2018; 53: 96-104.

[5] Öztürk Ö, Sarıkaya P, Özdemir Ş, Çikendin Z, Zünbül N. True and falses known by the mothers about mother milk and breastfeeding. JCP 2018; 16(2): 40-54. (In Turkish)

[6] Turkey Demographic and Health Survey 2018. Hacettepe University Institute of Population Studies in Ankara, Turkey. Available at http://www.hips.hacettepe.edu.tr/tnsa2018/ rapor/2018_TNSA_Ozet_Rapor.pdf (accessed 15.11.2019)

[7] Araz NÇ. Evaluation of socio-demographic factors that affecting to the initiation of breastfeeding in the neonatal period. Turkish J Pediatr Dis 2012; 6(4): 215-220. (Turkish)

[8] Karaçam Z, Sağlık M. Breastfeeding problems and interventions performed on problems: Systematic review based on studies made in Turkey. Turk Pediatri Ars 2018; 53(3): 134-148.

[9] Silva VA, Caminha MF, Silva SL, Serva V, Azevedo P, Filho MB. Maternal breastfeeding: indicators and factors associated with exclusive breastfeeding in a subnormal urban cluster assisted by the Family Health Strategy. J Pediatr (Rio J) 2018; 95: 298305. 
[10] Kronborg H, Foverskov E, Væth M, Maimburg RD. The role of intention and self-efficacy on the association between breastfeeding of first and second child, a Danish cohort study. BMC Pregnancy Childb 2018; 18(1): 1-9.

[11] Vehling L, Chan D, McGavock J, Becker AB, Subbarao P, Moraes TJ, Mandhane PJ, Turvey SE, Lefebvre DL, Sears MR, Azad MB. Exclusive breastfeeding in hospital predicts longer breastfeeding duration in Canada: Implications for health equity. Birth 2018; 45: 440-449.

[12] Jiang M, Gao H, Vinyes-Pares G, Yu K, Ma D, Qin X, Wang P. Association between breastfeeding duration and postpartum weight retention of lactating mothers: A meta-analysis of cohort studies. Clin Nutr 2018; 37(4): 1224-1231.

[13] Nelson JM, Li R, Perrine CG, Scanlon KS. Changes in mothers' intended duration of breastfeeding from the prenatal to neonatal periods. Birth 2018; 45(2): 178-183.

[14] Babakazo P, Donnen P, Akilimali P, Ali NMM, Okitolonda E. Predictors of discontinuing exclusive breastfeeding before six months among mothers in Kinshasa: A prospective study. Int Breastfeed J 2015; 10(1): 1-9.

[15] Sun K, Chen M, Yin Y, Wu L, Gao L. Why Chinese mothers stop breastfeeding: Mothers' self-reported reasons for stopping during the first six months. J. Child Health Care 2017; 21(3): 353-363.

[16] Gölbaşı Z, Eroğlu K, Kaya D. Determining the breast milk and breastfeeding myths of postpartum women. KOU Sag Bil Derg 2018; 4(2): 32-43. (Turkish)

[17] Moher D, Liberati A, Tetzlaff J, Altman DG. Reprint-preferred reporting items for systematic reviews and meta-analyses: The PRISMA statement. Physical Therapy 2009; 89: 873-880.

[18] Page MJ, McKenzie JE, Bossuyt PM, Boutron I, Hoffmann T, Mulrow CD, Shamseer L, Moher D. Updating the PRISMA reporting guideline for systematic reviews and meta-analyses: study protocol. Published online 2018; 14

[19] Karaçam Z. Systematic review methodology: A guide for preparation of systematic review. DEUHYO ED 2013; 6: 26-33. (Turkish)

[20] JBI Critical Appraisal Checklist for Studies Reporting Prevalence Data Available at http://joannabriggs.org/research/criticalappraisal-tools.html (accessed 18.03.2020)

[21] Can E, Küçükemre B, Poyrazoğlu Ş, Gökçay G, Baysal US. Characteristics of children and families attending a child health surveillance clinic. J Child 2008; 8(2): 96-101. (Turkish)

[22] Gölbaşı Z, Koç G. Beastfeeding behaviour of women during postpartum first six months and effect of prenatal breastfeeding attitude on postpartum breastfeeding. JOHUFON 2008; 15(1): 16-31. (Turkish)

[23] Ünalan PC, Akgün T, Çiftçili S, Boler i, Akman M. Why do mothers attending a baby-friendly mother and child health care unit start early solid food to their babies? Turk Pediatri Ars 2008; 43(2): 59-64. (Turkish)

[24] Yıldız A, Baran E, Akdur R, Ocaktan E, Kanyılmaz O. Breastfeeding status and effecting factors of mothers have 0-11 months babies at a health centre area. Journal of Ankara University Faculty of Medicine 2008; 61(2): 61-67. (Turkish)

[25] Yesildal N, Aytar G, Kocabay K, Mayda AS, Daglı SC, Bahcebasi T. Breastfeeding practices in Duzce, Turkey. J Hum Lact 2008; 24(4): 393-400.

[26] Gün I, Yılmaz M, Şahin H, Inanc N, Aykut M, Günay O, Öztürk A, Çıtıl R, Çiçek B, Ondan D, Tuna Ş. The breast-feeding status of 0-36-month-old children in Kayseri, Melikgazi education and research area. Çocuk Sağlığı ve Hastalıkları Dergisi 2009; 52: 176-182. (Turkish)

[27] Kondolot M, Yalçın S, Yurdakök K. The factors that affect exclusive breastfeeding status. Çocuk Sağlığı ve Hastalıkları Dergisi 2009; 52(3): 122-127. (Turkish)

[28] Çınar N, Sözeri C, Dede C, Cevahir R. Effects of breast feeding of mother and baby sleeping in the same room. Maltepe Üniversitesi Hemşirelik Bilim ve Sanat Dergisi, Sempozyum Özel Sayısı 2010; 235-241. (Turkish)

[29] Dolgun G, Yüksel A. Assessing mandated breastfeeding education in Istanbul. MCN Am J Matern Child Nurs 2010; 35(5): 293-296.

[30] Ince T, Kondolot M, Yalçın SS, Yurdakök K. Breastfeeding consultation status of mothers. Çocuk Sağlığı ve Hastalıkları Dergisi 2010; 53(3): 189-197. (Turkish)

[31] Akova S, Yazar AS, Güven Ş, Aydoğdu S, Toklucu MÖ, Tamer C. Evaluation of growth and development in breast-fed infants throughout 0-36 months. Dicle Medical Journal 2012; 39(4): 542-546. (Turkish)

[32] Çatak B, Sütlü S, Kılınç AS, Bağ D. Breastfeeding and nutrition patterns of babies in Burdur. Pamukkale Medical Journal 2012; 3(3): 115-122. (Turkish)

[33] Çeçe Ö, Yenal K. The factors that affect breastfeeding duration of working mothers. Cumhuriyet Hem Der 2012; 1(1): 10-17. (Turkish)

[34] Yiğitbaş Ç, Kahriman i, Çalık KY, Bulut HK. About the breastfeeding attitudes and behaviour of the mothers that gave birt in hospitals in Trabzon. GUJHS 2012; 1(2): 49-59. (Turkish)

[35] Beşbenli K, Avgen B, İncioğlu A, Çetinkaya F. The knowledge and practices of mothers from three different socioeconomic groups living in İstanbul on breastfeeding and supplementary foods. Çocuk Sağlığı ve Hastalıkları Dergisi 2013; 56: 76-81. (Turkish)

[36] Bülbül S, Kılınçkaya MF. 0-2 age group babies breastfeeding nutritional status and related factors. KÜTFD 2013; 15(1): 1520. (Turkish)

[37] Sabbağ Ç. Nutrition behaviours of rural and urban mothers on 0-24 month children. IJHSS 2013; 10(1): 279-292. (Turkish)

[38] Şahin H, Yılmaz M, Aykut M, Balcı E, Sağıroğlu M, Öztürk A. Risk factors for breastfeeding problems in mothers applied to two public healthcare centers in Kayseri province. Turk Pediatri Ars 2013; 48(2): 145-151.

[39] Yenal K, Tokat MA, Ozan YD, Çeçe Ö, Abalın FB. The relation between breastfeeding self-efficacy and breastfeeding successes of mothers. HEAD 2013; 10(2): 14-19. (Turkish)

[40] Şencan I, Tekin O, Tatlı MM. Factors influencing breastfeeding duration: A survey in a Turkish population. Eur. J. Pediatr. 2013; 172(11): 1459-1466.

[41] Sivri BB, Özpulat F. The knowledge and practices of mothers with 6 month-old babies related with the transition to solid complementary feeding food and breastfeeding. ACU Sağlık Bil Derg 2014; 5(1): 59-65. (Turkish)

[42] Çınar N, Köse D, Altınkaynak S. Breastfeeding self-efficacy of mothers and the affecting factors. Aquichan 2014; 14(3): 327335.

[43] Bostancı G, Inal S. The evaluation of knowledge and practice about breastfeeding of mothers who delivering at a private baby friendly hospital. HSP 2015; 2(3): 260-270. (Turkish)

[44] Dinç A, Dombaz I, Dinç D. Traditional practices related to breast milk and breastfeeding of mothers with babies of 6-18 months. Balıkesir Sağlık Bil Derg 2015; 4(3): 125-130. (Turkish) 
[45] Demirtas B. Multiparous mothers: Breastfeeding support provided by nurses. Int J Nurs Pract 2015; 21(5): 493-504.

[46] Erkuran N, Sac UR, Taşar AM, Dallar Y. Frequency and demographics of exclusive breastfeeding in turkish women in Ankara. Acta Med Anatol 2015; 3(3): 92-98.

[47] Karadağ M, Aydın S, Yılmaz Y, Elmas Ş. Breastfeeding status of the babies under six months of age. STED 2016; 25(1): 22-27. (Turkish)

[48] Çalık KY, Çetin FC, Erkaya R. Breastfeeding practices of mothers and influencing practices. GUSBD 2017; 6(3): 80-91. (Turkish)

[49] Gümüştakım RŞ, Aksoy HD, Cebeci SE, Kanuncu S, Çakır L, Yavuz E. Evaluation of eating habits in children 0-2 years of age: A multicenter study. Fam Pract Palliat Care 2017;2(1):18. (Turkish)

[50] Ince T, Aktaş G, Aktepe N, Aydın A. The evaluation of the factors affecting mothers' breastfeeding self-efficacy and breastfeeding success. Behçet Uz Çocuk Hast. Derg 2017; 7(3): 183-190. (Turkish)

[51] Koç Ö, Özkan H, Sidar N, Can D. Evaluating the knowledge, opinions, and attitudes of mothers regarding the breastfeeding coaching. J Contemp Med 2017; 7(2): 175-183. (Turkish)

[52] Şahin BB, Özyurt BC. Breastfeeding and nutrition habits of 0-24 month infants in a semi-urban region of Manisa. Turk J Public Health 2017; 15(3): 164-175. (Turkish)

[53] Yılmaz E, Öcal FD, Yılmaz ZV, Ceyhan M, Kara OF, Küçüközkan T. Early initiation and exclusive breastfeeding: Factors influencing the attitudes of mothers who gave birth in a baby-friendly hospital. Turk J Obstet Gynecol 2017; 14(1): 1-9.

[54] Canbay FÇ. Investigation of feeding patterns of babies born with caesarean for the first six month. JDU Health Sci Inst 2018; 8(1): 1-6. (Turkish)

[55] Derin DÖ, Erdoğan A. An investigation of breastfeeding practices of mothers: The sample of Muş. Turkiye Klinikleri J Health Sci 2018; 3(1): 1-13. (Turkish)

[56] Kırıc S, Görak G. The investigation of feeding condition of infants aged between 0-6 monthes. JHS 2018; 15(1): 375-385. (Turkish)

[57] Göl I. Antenatal care and breastfeeding. TJFMPC 2018; 12(2): 102-108.

[58] Keloglan S, Yılmaz A, Gümüş K. Factors affecting mothers' breastfeeding. IJCS 2018; 11(1): 225-230.

[59] Küçükkaya B, Dindar I, Semerci R, Sunar ST, Derleyen B, Kızılok EK. The relation between breastfeeding self-efficacy and starting times of supplementary food. IJCS 2018; 11(1): 231238.

[60] Salcan S, Topal I, Ates I. The frequency and effective factors of exclusive breastfeeding for the first six months in babies born in Erzincan province in 2016. Eurasian J Med 2018; 51(2): 145149.

[61] Kepekçi M, Yalçınoğlu N, Devecioğlu E, Eren T, Gökçay G. Evaluation of the activities of a breastfeeding counselling clinic. J Child 2012; 12(4): 164-168. (Turkish)
[62] Sökücü FY, Aslan E. The effect of woman's work status on breast-feeding. I.U.F.N. Hem. Derg 2012; 20(1): 62-68. (Turkish)

[63] Örün E, Yalçın S, Madendağ Y, Eras ZÜ, Dursun A, Mutlu B, Kutluk Ş, Yurdakök K. The effects of mothers' psychopathologies and sociodemographic characteristics on exclusive breastfeeding during postpartum 1-1.5 months. Çocuk Sağlığı ve Hastalıkları Dergisi 2009; 52(4): 167-175. (Turkish)

[64] Gökdemirel S, Yılmaz T, Nalbant H, Bulut A. The effect of breastfeeding counselling the mothers in the early period after birth on infant's exclusively breastfeeding. J.M.B. 2010; 59-63. (Turkish)

[65] Bolat F, Uslu S, Bolat G, Bülbül A, Arslan S, Çelik M, Cömert $S$, Nuhoğlu A. Factors affecting breast feeding in the first six months of life. J Child 2011; 11(1): 5-13. (Turkish)

[66] Smith HA, Hourihane JOB, Kenny LC, Kiely M, Murray DM, Leahy-Warren P. Early life factors associated with the exclusivity and duration of breastfeeding in an Irish birth cohort study. Midwifery 2015; 31(9): 904-911.

[67] Kushwaha AS, Kushwaha A, Kushwahan N. A study on initiation of breastfeeding: are children in India getting the best start?. Int J Community Med Public Health 2018; 5(7): 3029-3033.

[68] Bai DL, Fong DYT, Tarrant M. Previous breastfeeding experience and duration of any and exclusive breastfeeding among multiparous mothers. Birth 2015; 42(1): 70-77.

[69] Cox K, Binns CW, Giglia R. Predictors of breastfeeding duration for rural women in a high-income country: evidence from a cohort study. Acta Paedıatr 2015; 104(8): e350-e359.

[70] Odar SC Khalsa AS, Nabors LA, Merianos AL, Peugh J. Predictors of exclusive breastfeeding for 6 months in a national sample of us children. AJHP 2019; 33: 48-56.

[71] Mirkovic KR, Perrine CG, Scanlon KS, Grummer - Strawn LM. In the United States, a mother's plans for infant feeding are associated with her plans for employment. J Hum Lact 2014; 30(3): 292-297.

[72] Victora CG, Bahl R, Barros AJD, França GVA, Horton S, Krasevec J, Murch S, Sankar MJ, Walker N, Rollin NC. Breastfeeding in the 21st century: Epidemiology, mechanisms and lifelong effect. The Lancet 2016; 387: 475-490.

[73] Perrine CG, Scanlon KS, Li R, Odom E, Grummer - Strawn LM. Baby-friendly hospital practices and meeting exclusive breastfeeding intention. Pediatrics 2012; 130: 54-60.

[74] O'Connor M, Allen J, Kelly J, Gao Y, Kildea S. Predictors of breastfeeding exclusivity and duration in a hospital without Baby Friendly Hospital Initiative accreditation: A prospective cohort study. Women Birth 2018; 31(4): 319-324.

[75] Susiloretni KA, Hadi H, Blakstad MM, Smith ER, Shankar AH. Does exclusive breastfeeding relate to the longer duration of breastfeeding? A prospective cohort study. Midwifery 2019; 69: 163-171.

How to cite this article: Yilmaz T, Dinc H, Gunaydin S, Kacar N. Breastfeeding in Turkey: A Systematic Review. Clin Exp Health Sci 2021; 11: 604-616. DOI: 10.33808/ clinexphealthsci.840651 